\title{
Green manure and spatial arrangement in the sustainability improvement of lettuce-beet intercrops
}

\author{
Ítalo N. Silva ${ }^{1}$, Francisco Bezerra Neto ${ }^{1}$, Aurélio P. Barros Júnior ${ }^{1}$, \\ Jailma S. S. de Lima ${ }^{1}$, Thaíza M. de V. Batista² \& Hamurábi A. Lins ${ }^{1}$ \\ ${ }^{1}$ Universidade Federal Rural do Semi-Árido/Centro de Ciências Agrárias/Departamento de Ciências Agronômicas e Florestais. Mossoró, RN. E-mail: \\ italonunessilva@gmail.com - ORCID: 0000-0002-6983-8245; bezerra@ufersa.edu.br - ORCID: 0000-0001-9622-206X; aurelio.barros@ufersa.edu.br \\ (Corresponding author) - ORCID: 0000-0002-6983-8245; jailma@ufersa.edu.br - ORCID: 0000-0001-7584-592X; hamurabi_a_@hotmail.com - ORCID: \\ 0000-0002-4548-9108 \\ ${ }^{2}$ Instituto Federal de Educação, Ciência e Tecnologia do Rio Grande do Norte/Curso Técnico em Agropecuária/Campus Apodi. Apodi, RN. E-mail: \\ thaiza.batista@ifrn.edu.br - ORCID: 0000-0003-3884-8659
}

\section{Key words:}

organic fertilization

planting configuration

tuberous-leafy vegetable

intercropping

agronomic performance and

economic efficiency

\begin{abstract}
A B S T R A C T
Beet and lettuce are industrial vegetable crops valued for their high mineral, vitamin and fiber contents and for their additional health benefits. These crops are usually grown in intercrops in family production systems in a sustainable manner in semi-arid regions. This work aimed to evaluate the effects of incorporating different levels of hairy woodrose, as a green manure, on the agro-economic sustainability indicators of lettuce-beet intercrops, planted in different spatial arrangements and involving two successive croppings. The experimental design was a randomized complete blocks with treatments arranged in a $4 \mathrm{x}$ 3 factorial scheme, corresponding to four hairy woodrose levels incorporated into the soil $\left(6,19,32\right.$ and $45 \mathrm{tha}^{-1}$, dry basis) and three spatial arrangements between the component crops (2:2, 3:3 and 4:4), with four replications. The optimized agroeconomic performance of lettuce-beet intercropping was achieved with the incorporation of approximately $35.30 \mathrm{tha}^{-1}$ hairy woodrose. The lettuce crop contributed significantly to the productivity efficiency and sustainability of the intercropping with beet, compared to the single vegetable crops. The spatial arrangements between component crops did not affect the agroeconomic performance of the lettuce intercropped with beet.
\end{abstract}

\section{Palavras-chave:}

adubação orgânica

configuração de plantio

consórcio de hortaliças folhosas

e tuberosas

desempenho agronômico

e eficiência econômica

\section{Adubo verde e arranjo espacial na melhoria da sustentabilidade de consórcios de alface e beterraba}

\section{R E S U M O}

A beterraba e a alface são hortaliças de alto valor nutritivo pelo teor de sais minerais, vitaminas e de fibras e por seus benefícios adicionais à saúde. Essas culturas são geralmente cultivadas em consórcios em sistemas de produção familiar de forma sustentável em regiões semiáridas. Objetivou-se neste trabalho avaliar os efeitos de diferentes níveis de jitirana, como adubo verde, nos indicadores agroeconômicos de sustentabilidade de consórcios de alface-beterraba, em diferentes arranjos espaciais e em dois cultivos sucessivos. O delineamento experimental foi de blocos casualizados com os tratamentos dispostos em um esquema fatorial $4 \times 3$, correspondente a quatro níveis de jitirana incorporados ao solo $\left(6,19,32\right.$ e $45 \mathrm{t} \mathrm{ha}^{-1}$, em base seca) em três arranjos espaciais entre as culturas componentes (2:2, 3:3 e 4:4), com quatro repetições. O desempenho agroeconômico otimizado do consórcio de alface-beterraba foi alcançado com a incorporação de aproximadamente $35,30 \mathrm{t} \mathrm{ha}^{-1}$ de jitirana. A cultura da alface contribuiu significativamente para a eficiência produtiva e sustentabilidade da consorciação com a beterraba, em comparação com as culturas em monocultivo. Os arranjos espaciais entre as culturas componentes não afetaram o desempenho agroeconômico da alface consorciada com a beterraba. 


\section{INTRODUCTION}

The use of spontaneous species of the Caatinga biome as a green manure in intercropping involving tuberoses and leafy vegetables has provided success in these crop production systems (Grangeiro et al., 2011; Oliveira, et al., 2017). One of these species is the hairy woodrose (Merremia aegyptia L.), an herbaceous plant with a climbing habit, annual, succulent, easy to cut and sting, being a genus of Convolvulaceae family. It establishes in environments with sandy, clayey and/or sandyclayey soils, presenting rapid growth, reaching up to $5 \mathrm{~m}$ in length (Linhares, 2013).

This species is widely available in the region, found in forests, fences, clearings in the forest and fields, producing enough seeds as a means of propagation and maintenance in the biome, without problems of environmental liberation, growing and developing in soils of different textures (Linhares et al., 2008; Lacerda et al., 2015). The hairy woodrose can achieve a green biomass productivity of $36 \mathrm{tha}^{-1}$, containing in terms of dry basis $26.2 \mathrm{~g} \mathrm{~kg}^{-1} \mathrm{~N}, 1.7 \mathrm{~g} \mathrm{~kg}^{-1} \mathrm{P}, 12.0 \mathrm{~g} \mathrm{~kg}^{-1} \mathrm{C}, 12.0 \mathrm{~g} \mathrm{~kg}^{-1} \mathrm{~K}, 6.0 \mathrm{~g} \mathrm{~kg}^{-1}$ $\mathrm{Ca}$ and $7.8 \mathrm{~g} \mathrm{~kg}^{-1} \mathrm{Mg}$. Therefore, it is as an important alternative for use as green manure in family farms producing vegetables in intercropping systems (Linhares, 2009).

It is known that fertilization with this species increases the percentage of organic matter in the soil and reduces soil acidity and toxic aluminum, an important benefit in the sustainability of the intercrops (Batista et al., 2016b). In addition, this practice promotes improvement of soil structure and aeration, as well as the moisture storage capacity, thus having a regulatory effect on soil temperature (Silva et al., 2013). It delays phosphorus fixation by increasing cation exchange capacity (CEC), helping to maintain potassium, calcium, magnesium and other elements available to plants (Batista et al., 2012).

The spatial arrangement is another essential handling factor that can be manipulated to improve the use of environmental resources and the efficiency of intercropped systems with vegetable crops. The efficiency, in which the component crops use solar radiation in an intercropping system, strongly depends on the planting pattern (Undie et al., 2012). However, to obtain promising results in the use of intercropping systems, the appropriate handling of production factors, such as green manuring and spatial arrangements between the components crops should be performed.

The current study aimed evaluating the effect of incorporating different amounts of hairy woodrose added to the soil, as well as the influence of the spatial arrangements, on the sustainability improvement in two croppings of lettuce intercropped with beet, through agronomic indices and economic indicators.

\section{Material AND Methods}

The present work was conducted from September to December 2011 at the Rafael Fernandes farm of the Universidade Federal Rural do Semi-Árido - UFERSA. The area is located in the Alagoinha district, $20 \mathrm{~km}$ northeast of Mossoró, Brazil (5' $11^{\prime} \mathrm{S}$ and $37^{\circ} 20^{\prime} \mathrm{W}, 18 \mathrm{~m}$ altitude). The climate is semiarid and, based on Köppen's climate classification, is type "BShw", namely dry and very hot. There are two distinctive seasons that include the dry season from June to January and the rainy season from February to May (Oliveira et al., 2012). The soil of the experimental area was classified as a Eutrophic Yellow-Red Ultisol, EMBRAPA (2006), which was sampled at a depth of 0-20 cm and mixed to homogeneity. The soil analyzes were performed at the Laboratory of Soil Fertility and Nutrition of the Department of Environmental Sciences and Technology of Plants, UFERSA, obtaining the following results: $\mathrm{pH}$ (in water) $=6.8$; organic matter $=11.5 \mathrm{mg} \mathrm{dm}^{-3} ; \mathrm{P}=6.3 \mathrm{mg} \mathrm{dm}^{-3} ; \mathrm{K}=85.2 \mathrm{mg} \mathrm{dm}^{-3} ; \mathrm{Ca}$ $=2.01 \mathrm{cmol}_{\mathrm{c}} \mathrm{dm}^{-3} ; \mathrm{Mg}=1.09 \mathrm{cmol} \mathrm{dm}_{\mathrm{c}} \mathrm{dm}^{-3} \mathrm{Na}=35.9 \mathrm{mg} \mathrm{dm}{ }^{-3}$; sum of bases $=3.47 \mathrm{cmol} \mathrm{dm}^{-3}$, and base saturation $=91 \%$.

The $\mathrm{pH}$ analysis was performed using a potentiometer in a soil suspension of 1:2.5 in water. For $\mathrm{P}$ and $\mathrm{K}$ content, the Mehlich solution ( $\mathrm{HCl} 0.05 \mathrm{~mol} \mathrm{~L}^{-1} \mathrm{H}_{2} \mathrm{SO}_{4}+0.025 \mathrm{~mol} \mathrm{~L}^{-1}$ ) extractor was used and $\mathrm{P}$ and $\mathrm{K}$ were determined by calorimetry and flame photometry, respectively. The content of calcium and magnesium was obtained by extraction with $1 \mathrm{~mol} \mathrm{~L}^{-1} \mathrm{KCl}$ and quantified by atomic absorption spectrophotometry and by titration with $0.01 \mathrm{~mol} \mathrm{~L}^{-1} \mathrm{NaOH}$, respectively. The percentage of carbon was determined by dichromatometry and $\mathrm{N}_{\text {total }}$ by the Kjeldahl method. Sodium was determined by dilute hydrochloric acid solution and was subsequently determined using flame spectrophotometric apparatus. The sum of bases was obtained by applying the following formula: $\mathrm{SB}=\mathrm{Ca}^{+2}$ $+\mathrm{Mg}^{+2}+\mathrm{K}^{+}+\mathrm{Na}^{+}$. The percentage of base saturation was obtained using the following formula: $\mathrm{V}(\%)=(\mathrm{SB} / \mathrm{CECpH} 7)$ $\times 100$, and electrical conductivity was measured using a conductivity meter (EMBRAPA, 2009).

The experiment was performed in a randomized complete block design, with the treatments arranged in a $4 \times 3$ factorial scheme, with four replications. The first factor corresponded to the amounts of hairy woodrose incorporated into the soil $\left(6,19,32\right.$ and $45 \mathrm{tha}^{-1}$, on a dry basis), and the second, the spatial arrangements $(2: 2,3: 3$ and $4: 4)$.

The intercropping systems were established in alternating strips of the component crops, using 50\% proportion of the area for beet and $50 \%$ of the remaining area for lettuce. The experimental plots consisted of two strips of two rows, in the 2:2 arrangement, two strips of three rows in the 3:3 arrangement, and two strips of four rows in the $4: 4$ arrangement, flanked by two beet border rows on one side and two border rows of lettuce on the other side, thereby constituting the side borders (Figure 1). The plot harvest area was $0.82,1.2$ and $1.6 \mathrm{~m}^{2}$, for the $2: 2$, $3: 3$ and 4:4 arrangement, respectively, with a corresponding 20 lettuce and 40 beet, 30 lettuce and 60 beet, and 40 lettuce and 80 beet plants. The spacing in the $4: 4$ arrangement was $0.20 \times 0.10 \mathrm{~m}$ for lettuce and $0.20 \times 0.05 \mathrm{~m}$ for beet, giving a population density of 250,000 lettuce (Almeida et al., 2015) and 500,000 beet plants, respectively (Silva et al., 2011).

In each block, single plots of lettuce and beet were planted and fertilized, according to research recommendations, at 6.68 and $44.90 \mathrm{t} \mathrm{ha}^{-1}$ (Góes et al., 2011; Bezerra Neto et al., 2011; Silva, 2013), respectively, to obtain the agroeconomic efficiency indices of each unit in the intercropped systems. The monocrop of each vegetable crop was established by planting six rows per plot. For the lettuce crop, the total area was $3.60 \mathrm{~m}^{2}$, the harvest area was $2.00 \mathrm{~m}^{2}$ and the spacing was $0.20 \mathrm{x} 0.20 \mathrm{~m}$. 


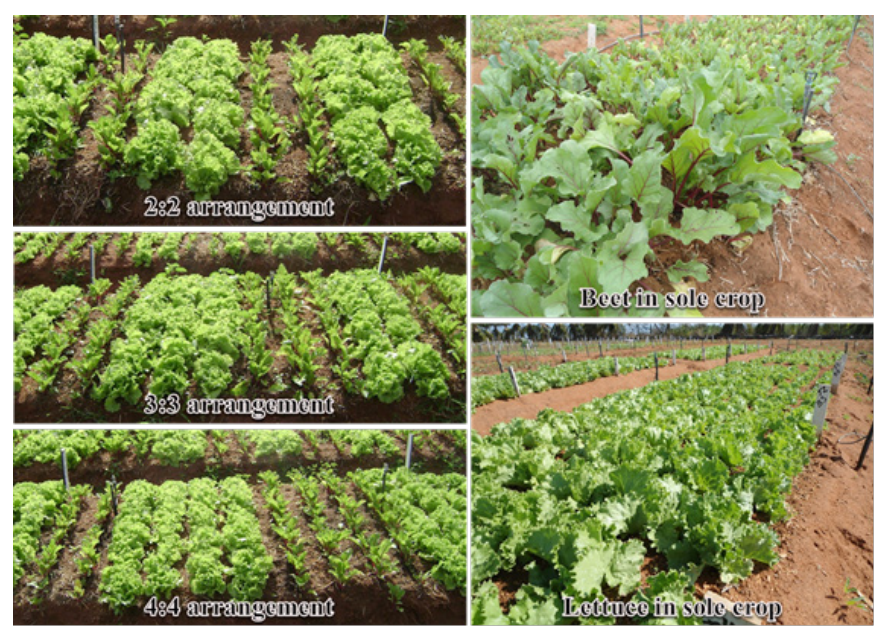

Figure 1. Spatial arrangements between the lettuce and beet crops in intercropping systems

For the beet crop, the total area was $1.44 \mathrm{~m}^{2}$, the harvest area was $0.80 \mathrm{~m}^{2}$ and the spacing was $0.20 \times 0.10 \mathrm{~m}$. The harvest area consisted of four central rows of plants, excluding the first and last plants of each row, which were used as borders.

The soil was manually cleaned with the aid of a hoe, followed by harrowing and lifting of the beds. Next, solarization was performed as a pre-planting treatment with transparent plastic type Vulca Brilho Bril Fles (30 microns) for 45 days, to reduce nematodes, particularly Meloidogyne spp. and plant parasites in the top $0-10 \mathrm{~cm}$ of the soil.

For fertilization of the plots, aerial part of hairy woodrose plants from up to $5 \mathrm{~m}$ in length were collected from several areas of native vegetation in Mossoró and in the rural zone of Tibau, Rio Grande do Norte State, in the stage before plant maturation. Given the abundance of this species in the Caatinga biome, its plants have been used rationally without requiring an environmental license to support its use as green manure or as hay for animal feed.

These shoots were crushed into $2 \mathrm{~cm}$ pieces in a forage machine, dried in the shade for about 5 days to reach the point of hay (approximately 10\% of moisture), quantified and stored for later use. Five single samples were taken and transformed in a composite sample. In the sequence, it was sent to the laboratory for analysis. The following results were obtained: $\mathrm{N}=20.10 \mathrm{~g} \mathrm{~kg}^{-1} ; \mathrm{P}=3.79 \mathrm{~g} \mathrm{~kg}^{-1} ; \mathrm{K}=16.40 \mathrm{~g} \mathrm{~kg}^{-1} ; \mathrm{Ca}=1.8 \mathrm{~g} \mathrm{~kg}^{-1}$; $\mathrm{Mg}=3.3 \mathrm{~g} \mathrm{~kg}^{-1}$, and $\mathrm{S}=1.3 \mathrm{~g} \mathrm{~kg}^{-1}$.

The chemical analyses for the determination of the nutrient contents present in each fraction were conducted using extracts obtained via sulfur digestion. Nitrogen was quantified by the Kjeldahl semi-micro method; phosphorus by the spectrometry method with vanadium yellow; potassium using the method of emission flame spectrometry; calcium and magnesium by the spectrometry method of atomic absorption and sulfur by the turbidimetry method (EMBRAPA, 2009). The amounts of each macronutrient applied in each dose of the green manure studied are in Table 1.

The plots were fertilized twice in the $0-20 \mathrm{~cm}$ soil layer. The first fertilization used $40 \%$ of the amounts relative to each plot, at 20 days before planting the tuberous vegetable, according to methodology used by Silva et al. 2013. The remaining $60 \%$ was incorporated at 40 days after planting of the crops. Once
Table 1. Amounts of each macronutrient applied to each dose of green manure incorporated into the soil

\begin{tabular}{crrrrrr}
\hline $\begin{array}{c}\text { Green manure } \\
\text { doses }\left(\mathbf{t} \mathbf{~ h a}^{-1}\right)\end{array}$ & $\mathbf{N}$ & $\mathbf{P}$ & $\mathbf{K}$ & $\mathbf{C a}$ & $\mathbf{M g}$ & \multicolumn{1}{c}{$\mathbf{S}$} \\
\cline { 2 - 7 } & 120.6 & 22.74 & 98.4 & 10.8 & 19.8 & 7.8 \\
19 & 381.9 & 720.1 & 311.6 & 34.2 & 62.7 & 24.7 \\
32 & 643.2 & 121.3 & 524.8 & 57.6 & 105.6 & 41.6 \\
45 & 904.5 & 170.5 & 738.0 & 81.0 & 148.5 & 58.5 \\
\hline
\end{tabular}

the hairy woodrose was incorporated into the soil, irrigation was performed twice daily (morning and evening), providing a water amount of approximately $8 \mathrm{~mm} \mathrm{~d}^{-1}$ (Lima et al., 2007), in order to promote the microbial activity of the soil in the decomposition process. Weed control was performed manually, $15,25,35$ and 45 days after sowing.

The lettuce and beet cultivars planted were "Tainá" and "Early Wonder", since they are adapted for growing in the Northeast region. The lettuce was sown in polystyrene trays with 128 cells, containing the commercial substrate Expanded Vermiculite - type B, with the following chemical composition: $\mathrm{S}_{\mathrm{i}} \mathrm{O}_{2}=45.10 \%, \mathrm{MgO}=23.60 \%, \mathrm{Al}_{2} \mathrm{O}_{3}=10.20 \%, \mathrm{Fe}_{2} \mathrm{O}_{3}=5.80 \%$, $\mathrm{K}_{2} \mathrm{O}=0.50 \%, \mathrm{Na}_{2} \mathrm{O}=0.10 \%, \mathrm{CaO}=3.60 \%, \mathrm{TiO}_{2}=0.70 \%, \mathrm{BaO}$ $=0.20$, and $\mathrm{H}_{2} \mathrm{O}$ (total) $=10.20 \%$. Three seeds were sown in each cell of the tray, and 10 days after the emergence, thinning was performed, leaving one seedling per cell. The lettuce seedlings were produced hydroponically inside a greenhouse covered with a white nylon mesh. The lettuce transplanting and beet sowing were performed on 5 October 2011, in holes about 3" deep, by placing one lettuce seedling into each hole and 3-4 beet seeds per hole. The beet thinning was done at 14 days after germination, leaving only one plant per hole. The lettuce was harvested at 30 days from transplanting. On 29 November 2011, the second planting of lettuce occurred. The cropping handlings were done in the same way as the first cultivation. The beet was harvested at 70 days after sowing and the harvest of the second lettuce cultivation occurred at 28 days after transplanting.

Yields were recorded in terms of green biomass for lettuce and roots for beet (the commercial products in each case) and the land equivalent ratio (LER), and the productive efficiency index (PEI) were determined. The economic indicators obtained were gross return (GR), net return (NR), the rate of return (RR), and net profit margin (NPM).

The LER was obtained by the following expression (Eq. 1):

$$
\mathrm{LER}=\frac{\mathrm{Yl} \mathrm{l}_{1} \mathrm{Y}}{\mathrm{Yl}_{1} \mathrm{~m}}+\frac{\mathrm{Yl}_{2} \mathrm{~b}}{\mathrm{Yl}_{2} \mathrm{~m}}+\frac{\mathrm{Ylb}}{\mathrm{Ybm}}
$$

where:

$\mathrm{Yl}_{1} \mathrm{~b}$ - fresh mass yield of lettuce in the first cropping in intercropping with beet;

$\mathrm{Yl}_{1} \mathrm{~m}$ - fresh mass yield of lettuce in the first cropping in monocropping;

$\mathrm{Yl}_{2} \mathrm{~b}$ - fresh mass yield of lettuce in the second cropping in intercropping with beet;

$\mathrm{Yl}_{2} \mathrm{~m}$ - fresh mass yield of lettuce in the second cropping in monocropping;

Ylb - fresh mass yield of lettuce and commercial productivity of beetroots in intercropping; and, 
Ybm - commercial productivity of beetroots in monocropping.

In calculating the PEI of each treatment, the Data Envelopment Analysis (DEA) model with constant returns to the scale (Mello et al., 2013) was used, since there was no significant difference between scales. This model had the following mathematical formulation:

$\operatorname{Max} \sum_{\mathrm{i}=1}^{\mathrm{r}} \mathrm{v}_{\mathrm{i}} \mathrm{x}_{\mathrm{io}} \sum_{\mathrm{j}=1}^{\mathrm{s}} \mathrm{u}_{\mathrm{j}} \mathrm{y}_{\mathrm{jo}}=1 \sum_{\mathrm{j}=1}^{\mathrm{s}} \mathrm{u}_{\mathrm{j}} \mathrm{y}_{\mathrm{jk}}-\sum_{\mathrm{i}=1}^{\mathrm{r}} \mathrm{v}_{\mathrm{i}} \mathrm{x}_{\mathrm{ik}} \leq 0, \mathrm{k}=1, \ldots, \mathrm{n}$

$u_{j}, v_{i} \geq 0, i=1, \ldots, s, j=1, \ldots, r$ where:

$\mathrm{X}_{\mathrm{ik}} \quad$ - input i value $(\mathrm{i}=1, \ldots, \mathrm{s})$ for treatment $\mathrm{k}(\mathrm{k}=1, \ldots, \mathrm{n})$;

$\mathrm{Y}_{\mathrm{jk}} \quad$ - output $\mathrm{j}$ value $(\mathrm{j}=1, \ldots, \mathrm{r})$ for treatment $\mathrm{k}$;

$\mathrm{v}_{\mathrm{i}}$ and $\mathrm{u}_{\mathrm{j}}$ - weights assigned to inputs and outputs, respectively; and,

O - treatment being analyzed.

In the modeling of this study, the RR (index described in the following item) was used as input.

The GR was obtained through the value of the production per hectare based on the price paid to producers in the region in February 2012. For beet, the amount paid was $\mathrm{R} \$ 0.90 \mathrm{~kg}^{-1}$ and for lettuce, it was $\mathrm{R} \$ 1.40 \mathrm{~kg}^{-1}$. The current exchange rate of the US dollar was $\$ 1=\mathrm{R} \$ 3.10$, in February 2016.

The GR is represented by the following expression:

$$
\mathrm{GR}=\mathrm{Y}_{\mathrm{bl}} \mathrm{P}_{\mathrm{b}}+\mathrm{Y}_{\mathrm{lb}} \mathrm{P}_{1}
$$

where:

$\mathrm{Y}_{\mathrm{bl}}$ and $\mathrm{Y}_{\mathrm{lb}}$ - yields $\left(\mathrm{t} \mathrm{ha}^{-1}\right)$ of beet and lettuce, respectively, as intercrops; and,

$\mathrm{P}_{\mathrm{b}}$ and $\mathrm{P}_{1}$ - prices of $1 \mathrm{~kg}$ of beet and lettuce, respectively, charged by the region's producers.

The NR was calculated as:

$$
\mathrm{NR}=\mathrm{GR}-\mathrm{PC}
$$

where:

PC (production costs) - summation of all expenses (input and labor) in each intercropping system.

The RR was obtained as:

$$
\mathrm{RR}=\frac{\mathrm{GR}}{\mathrm{PC}}
$$

The NPM was got as the ratio of NR to GR, expressed as a percentage.

Univariate analysis of variance for the factorial experiment in a randomized complete block design was performed to evaluate the indices and indicators studied, using SISVAR (Ferreira, 2011). Systat Software (2011) was used to adjust the regression curves, allowing estimation of the behavior of each index as a function of the amounts of hairy woodrose biomass incorporated into the soil. Tukey's test at $5 \%$ probability was used to compare average values between spatial arrangements.

\section{Results AND Discussion}

No significant interactions were found between the amounts of hairy woodrose incorporated into the soil and the spatial arrangements in terms of the variables LER, PEI and partial land equivalent ratio for lettuce (PLERl) and for beet (PLERb) (Figure 2).
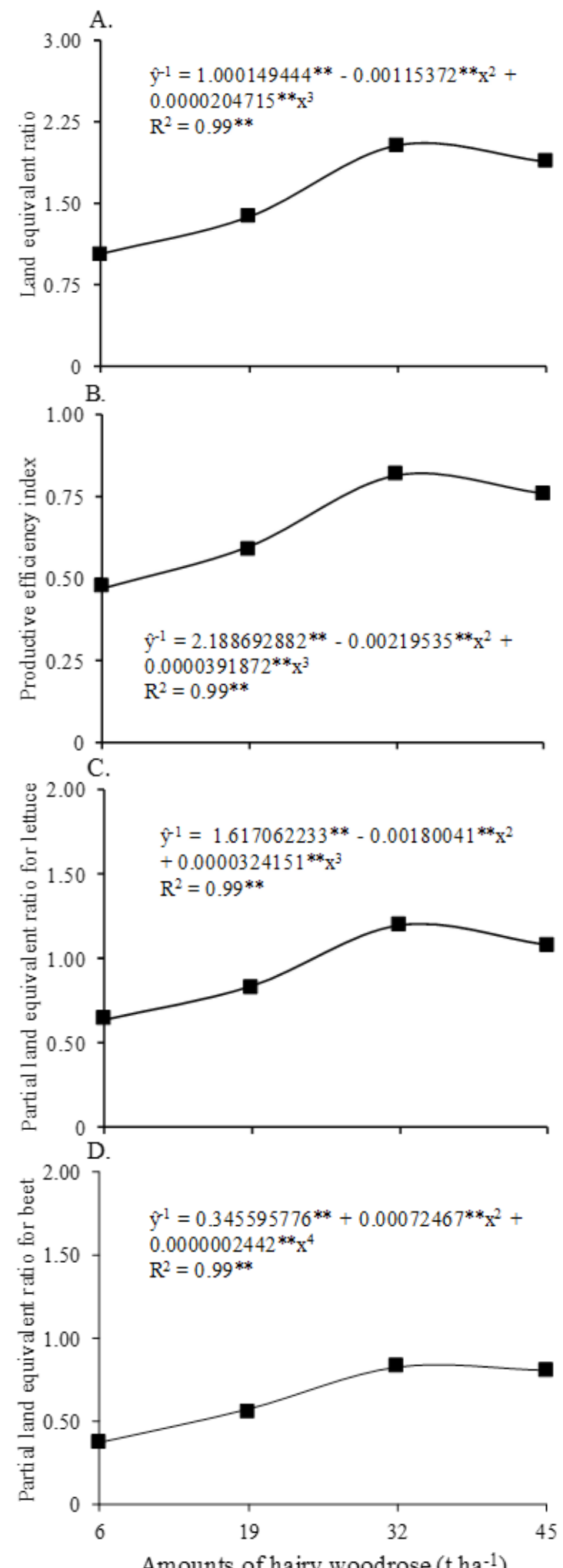

Figure 2. Land equivalent ratio (A), productive efficiency index (B), and partial land equivalent ratios for lettuce (C) and beet (D) as a function of hairy woodrose amounts incorporated into the soil 
These variables increased with increasing amounts of hairy woodrose added to the soil, until the maximum values of 2.18 (for LER), 0.86 (for PEI) (Figures 2A and B), 1.26 (for PLERl) and 0.88 (for PLERb) (Figures 2C and D), obtained at 37.57, $37.35,37.03$ and $38.52 \mathrm{tha}^{-1}$, respectively, then decreased, until the larger amount of green manure was incorporated.

The maximum value of 2.18 in the LER means the sole crop requires $118 \%$ more area to produce the equivalent output in intercropping system per hectare. According to Jagannath \& Sunderaraj (1987), the advantage of intercropping system measured by LER, comes from two sources: (a) the land factor (area occupied by crops) and (b) the agronomic/biological factor (arising of the treatments tested).

The complementarity of the crops involved in the intercropping system can be considered when the income of the intercropping system is higher than that obtained from an area planted with the single crops, thus, indicating a biological advantage in the production of the intercropping system. The LERs from intercropping were greater than 1 . Therefore, a more efficient use of the environmental resources occurred in these systems compared to the monocrops. LER values greater than 1 were also obtained in intercropping systems between leafy crops and/or leafy and tuberous crops, such as carrots and lettuce (Bezerra Neto et al., 2010; Oliveira et al., 2004), arugula and coriander (Moreira, 2011) and carrot and arugula (Batista et al., 2016a).

Based on the partial LERs of the crops, it is possible to observe the expressive contribution of the lettuce crop, in terms of the production of green biomass, to the intercropping system relative to its single crop (Figure 2). From this result, it is inferred the best use of environmental resources by lettuce when compared with beet.

There was no significant difference between the spatial arrangements in the LER, PEI and in the land equivalent ratios of lettuce $\left(\mathrm{LER}_{\mathrm{l}}\right)$ and beet $\left(\mathrm{LER}_{\mathrm{b}}\right)$ (Table 2$)$.

There were no significant interactions between the amounts of hairy woodrose incorporated into the soil and spatial arrangements regarding the gross income (GI), net income $(\mathrm{NI})$, rate of return (RR) and net profit margin (NPM) (Figure 3 ). Increases in these economic indicators were observed with increasing amounts of hairy woodrose added, until the maximum of $\mathrm{R} \$ 46,032.07$ (GI), R\$22,671.62 (NI), 2.01 (RR) and $49.46 \%$ (NPM), at $37.54,35.44,34.87$ and $35.34 \mathrm{t} \mathrm{ha}^{-1}$ of green manure, respectively, followed by decreases, until the largest amount of green manure was incorporated into the soil.

The increasing response in all variables analyzed, as a function of the increasing application of hairy woodrose to the maximum point, can be attributed to a higher nutrient supply

Table 2. Land equivalent ratio (LER), productive efficiency index (PEI), and partial land equivalent ratios for lettuce $\left(\operatorname{LER}_{\mathrm{l}}\right)$ and beet $\left(\mathrm{LER}_{\mathrm{b}}\right)$ as a function of the spatial arrangement

\begin{tabular}{ccccc}
\hline $\begin{array}{c}\text { Spatial } \\
\text { arrangement }\end{array}$ & LER & PEI & LER $_{\mathbf{I}}$ & LER $_{\mathbf{b}}$ \\
$2: 2$ & $1.57 \mathrm{a}^{\star}$ & $0.64 \mathrm{a}$ & $0.89 \mathrm{a}$ & $0.68 \mathrm{a}$ \\
$3: 3$ & $1.61 \mathrm{a}$ & $0.66 \mathrm{a}$ & $0.94 \mathrm{a}$ & $0.67 \mathrm{a}$ \\
$4: 4$ & $1.58 \mathrm{a}$ & $0.69 \mathrm{a}$ & $0.99 \mathrm{a}$ & $0.60 \mathrm{a}$ \\
\hline
\end{tabular}

Means followed by the same lowercase letters in columns do not differ by Tukey's test at 0.05 probability

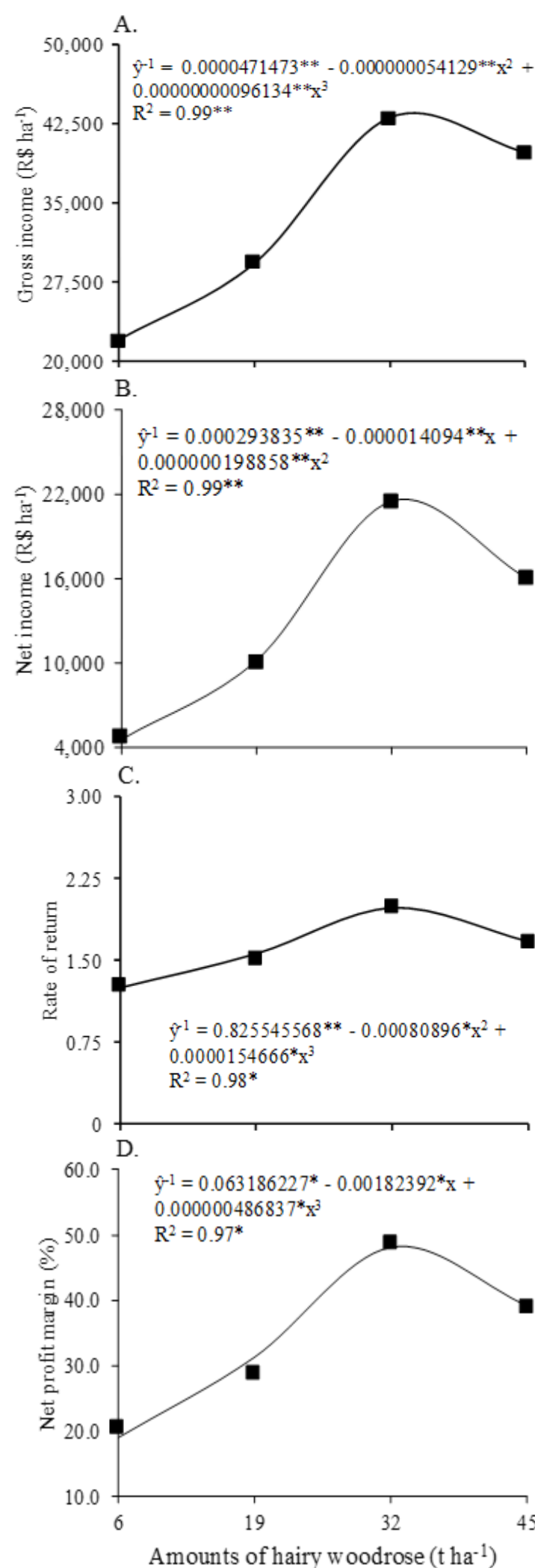

Figure 3. Gross income (A), net income (B), rate of return (C) and net profit margin (D) as a function of amounts of hairy woodrose incorporated into the soil

for plants, proper synchronization between the decomposition and mineralization of the hairy woodrose, and the time of greatest nutritional requirement of the crops (Fontanétti et al., 2006). According to Sala et al. (2015), the proper application of nutrients in the soil will promote an increase in plant productivity up to a maximum point, from which the response becomes negative. 
The current results are similar to those obtained by Grangeiro et al. (2011), who evaluated the agroeconomic benefits of beet and coriander intercropping, with GI and NI of $\mathrm{R} \$ 28,988.32$ and $21,285.32$, respectively. NI is an indicator that better expressed the economic value of intercropping systems than GI, because it deducts the production costs (Oliveira et al., 2004). This index indicates that the agronomic superiority obtained in the intercrops was translated into an economic advantage.

There was no significant difference between the spatial arrangements tested in the economic indicators evaluated (Table 3). These results corroborate those obtained for the agronomic variables of the lettuce-beet intercrop.

Table 3. Gross income $(\mathrm{Gl})$, net income $(\mathrm{NI})$, rate of return (RR) and net profit margin (NPM) as a function of spatial arrangements

\begin{tabular}{|c|c|c|c|c|}
\hline \multirow{2}{*}{$\begin{array}{c}\text { Spatial } \\
\text { arrangements }\end{array}$} & $\mathrm{GI}$ & $\mathrm{NI}$ & \multirow{2}{*}{ RR } & \multirow{2}{*}{$\begin{array}{l}\text { NPM } \\
(\%)\end{array}$} \\
\hline & \multicolumn{2}{|c|}{ (R\$ ha-1) } & & \\
\hline $2: 2$ & $33,136.00 a^{*}$ & $12,732.00 \mathrm{a}$ & $1.60 \mathrm{a}$ & $31.58 a$ \\
\hline $3: 3$ & $33,943.00 \mathrm{a}$ & $13,539.00 \mathrm{a}$ & $1.64 \mathrm{a}$ & $35.13 a$ \\
\hline $4: 4$ & $33,483.00 \mathrm{a}$ & $13,078.00 \mathrm{a}$ & $1.62 \mathrm{a}$ & $36.32 a$ \\
\hline
\end{tabular}

${ }^{*}$ Means followed by the same lowercase letters in columns do not differ by Tukey's test at 0.05 probability

\section{Conclusions}

1. The optimized agroeconomic performance of lettucebeet intercropping was achieved with the incorporation of approximately $35.30 \mathrm{t} \mathrm{ha}^{-1}$ of hairy woodrose.

2. The lettuce crop contributed significantly to the productivity efficiency and sustainability of the intercropping with beet, compared to the single vegetable crops.

3. The spatial arrangements between component crops did not affect the agro-economic performance of the lettuce bicropping intercropped with beet.

4. The dry hairy woodrose showed it is a feasible green manure in the association of lettuce with beet.

\section{ACKNOWLEDGements}

Special thanks to the Coordenação de Aperfeiçoamento de Pessoal de Nível Superior for financially supporting this research. To the research group that develops technologies for growing vegetables on family farms. To the Conselho Nacional de Desenvolvimento Cientifico e Tecnológico for providing a research grant.

\section{Literature Cited}

Almeida, A. E. da S.; Bezerra Neto, F.; Costa, L. R.; Silva, M. L. da; Lima, J. S. S. de; Barros Júnior, A. P. Eficiência agronômica do consórcio alface-rúcula fertilizado com flor-de-seda. Revista Caatinga, v.28, p.79-85, 2015. https://doi.org/10.1590/198321252015v28n309rc

Batista, M. A. V.; Vieira, L. A.; Souza, J. P.; Freitas, J. D. B. de; Bezerra Neto, F. Efeito de diferentes fontes de adubação sobre a produção de alface no município de Iguatu-CE. Revista Caatinga, v.25, p.8-11, 2012.
Batista, T. M. de V.; Bezerra Neto, F.; Porto, V. C. N.; Barros Júnior, A. P.; Silva, I. N.; Silva, M. L. da; Lima, J. S. S. de; Oliveira, E. Q. de. Bio-agro-economic returns from carrot and salad rocket as intercrops using hairy woodrose as green manure in a semi-arid region of Brazil. Ecological Indicators, v.67, p.458-465, 2016 a. https://doi.org/10.1016/j.ecolind.2016.03.018

Batista, T. M. de V.; Bezerra Neto, F.; Silva, I. N.; Silva, M. L. da; Oliveira, E. Q. de; Barros Júnior, A. P. Agronomic efficiency of the intercropping of arugula with carrot under different population combinations. Revista Caatinga, v.29, p.76-84, 2016b. https://doi. org/10.1590/1983-21252016v29n109rc

Bezerra Neto, F.; Góes, S. B.; Sá, J. R.; Linhares, P. C. F.; Góes, G. B.; Moreira, J. N. Desempenho agronômico da alface em diferentes quantidades e tempos de decomposição de jitirana verde. Revista Brasileira de Ciências Agrárias, v.6, p.236-242, 2011. https://doi. org/10.5039/agraria.v6i2a977

Bezerra Neto, F.; Gomes, E. G.; Araújo, R. R. de; Oliveira, E. Q. de; Nunes, G. H. de S.; Grangeiro, L. C.; Azevedo, C. M. da S. B. Evaluation of yield advantage indexes in carrot-lettuce intercropping systems. Interciencia, v.35, p.59-64, 2010.

EMBRAPA - Empresa Brasileira de Pesquisa Agropecuária. Sistema brasileiro de classificação de solos. 2.ed. Rio de Janeiro: Embrapa Solos, 2006. 306p.

EMBRAPA- Empresa Brasileira de Pesquisa Agropecuária. Manual de análises químicas de solos, plantas e fertilizantes. 2.ed. rev. amp. Brasília: Embrapa Informação Tecnológica, 2009. 627p.

Ferreira, D. F. Sisvar: A computer statistical analysis system. Ciência e Agrotecnologia, v.35, p.1039-1042, 2011.

Fontanétti, A.; Carvalho, G. J. de; Gomes, L. A. A.; Almeida, K. de; Moraes, S. R. G. de; Teixeira, C. M. Adubação verde na produção orgânica de alface americana e repolho. Horticultura Brasileira, v.24, p.146-150, 2006. https://doi.org/10.1590/S010205362006000200004

Góes, S. B. de; Bezerra Neto, F.; Linhares, P. C. F.; Góes, G. B. de; Moreira, J. N. Productive performance of lettuce at different amounts and times of decomposition of dry scarlet starglory. Revista Ciência Agronômica, v.42, p.1036-1042, 2011. https:// doi.org/10.1590/S1806-66902011000400028

Grangeiro, C. L.; Santos, A. P.; Freitas, F. C. L.; Simão, L. M. C.; Bezerra Neto, F. Avaliação agronômica das culturas da beterraba e coentro em função da época de estabelecimento do consórcio. Revista Ciência Agronômica, v.42, p.242-248, 2011. https://doi. org/10.1590/S1806-66902011000100030

Jagannath, M. K.; Sunderaraj, N. Productivity equivalent ratio and statistical testing of its advantage in intercropping. Journal of the Indian Society of Agricultural Statistics, v.39, p.289-300, 1987.

Lacerda, M. A. de; Silva, R. A. da; Linhares, P. C. F.; Maracajá, P. B.; Pinto, M. do S. de C. Potencial forrageiro da jitirana (Merremia aegyptia) para a produção de feno no semiárido nordestino. Agropecuária Científica no Semiárido, v.11, p.44-52, 2015.

Lima, J. S. S. de; Bezerra Neto, F.; Negreiros, M. Z. de; Freitas, K. K. C. de; Barros Júnior, A. P. Desempenho agroeconômico de coentro em função de espaçamentos e em dois cultivos. Revista Ciência Agronômica, v.38, p.407-413, 2007. 
Linhares, P. C. F. Vegetação espontânea como adubo verde no desempenho agroeconômico de hortaliças folhosas. Mossoró: UFERSA, 2009. 109p. Tese Doutorado

Linhares, P. C. F. Adubação verde como condicionadora do solo. Revista Campo e Negócios, v.11, p.22-23, 2013.

Linhares, P. C. F.; Maracajá, P. B.; Lima, G. K. L.; Bezerra Neto, F.; Liberalino Filho, J. Resposta da rúcula (Eruca sativa Mill.) folha larga a adubação verde com jitirana (Ipomoea glabra L.) incorporada. Revista Verde Agroecologia e Desenvolvimento Sustentável, v.3, p.72-77, 2008.

Mello, J. C. C. B. S. de; Gomes, E. G. Eficiências aeroportuárias: Uma abordagem comparativa com análise de envoltória de dados. Revista de Economia e Administração, v.3, p.15-23, 2013.

Moreira, J. N. Consorciação de rúcula e coentro adubada com espécie espontânea sucedida pelo cultivo de rabanete. Mossoró: UFERSA, 2011. 115p. Tese Doutorado

Oliveira, E. Q. de; Bezerra Neto, F.; Negreiros, M. Z. de; Barros Júnior, A. P. Desempenho agroeconômico do bicultivo de alface em sistema solteiro e consorciado com cenoura. Horticultura Brasileira, v.22, p.712-717, 2004. https://doi.org/10.1590/S010205362004000400009

Oliveira, L. J. de; Bezerra Neto, F.; Lima, J. S. S. de; Oliveira, E. Q. de; Moreira, J. N.; Silva, I. N. Viability of polycultures of arugulacarrot-coriander fertilized with hairy woodrose under different population densities. Revista Brasileira de Engenharia Agrícola e Ambiental, v.21, p.611-617, 2017. https://doi.org/10.1590/18071929/agriambi.v21n9p611-617
Oliveira, M. K. T. de; Bezerra Neto, F.; Barros Júnior, A. P.; Moreira, J. N.; Sá, J. R. de; Linhares, P. C. F. Desempenho agroeconômico da cenoura adubada com jitirana (Merremia aegyptia). Horticultura Brasileira, v.30, p.433-439, 2012. https://doi.org/10.1590/S010205362012000300013

Sala, F.; Boldea, M.; Rawashdeh, H.; Nemet, I. Mathematical model for determining the optimal doses of mineral fertilizers for wheat crops. Pakistan Journal of Agricultural Sciences, v.52, p.609-617, 2015.

Silva, I. N. Bicultivo de alface consorciada com beterraba sob diferentes quantidades de jitirana incorporadas ao solo e arranjos espaciais. Mossoró: UFERSA, 2013. 73p. Dissertação Mestrado

Silva, M. L. da; Bezerra Neto, F.; Linhares, P. C. F.; Bezerra, A. K. H. Produção de cenoura fertilizada com flor-de-seda (Calotropis procera (Ait.) R. Br.). Revista Ciência Agronômica, v.44, p.732740, 2013. https://doi.org/10.1590/S1806-66902013000400009

Silva, M. L. da; Bezerra Neto, F.; Linhares, P. C. F.; Sá, J. R. de; Lima, J. S. S. de; Barros Júnior, A. P. Produção de beterraba fertilizada com jitirana em diferentes doses e tempos de incorporação ao solo. Revista Brasileira de Engenharia Agrícola e Ambiental, v.15, p.801809, 2011. https://doi.org/10.1590/S1415-43662011000800006

Systat Software. Sigma plot for windows version 12.0. San Jose: Systat Software Inc., 2011.

Undie, U. L.; Uwah, D. F.; Attoe, E. E. Effect of intercropping and crop arrangement on yield and productivity of late season maize/ soybean mixtures in the humid environment of South Southern Nigeria. Journal of Agricultural Science, v.4, p.37-50, 2012. https:// doi.org/10.5539/jas.v4n4p37 